Bond University

Research Repository

\title{
:
}

\section{Sustainable Project-oriented Careers: A Conceptual Model}

Skulmoski, Gregory James; Langston, Craig Ashley; Patching, Alan; Ghanbaripour, Amir

Published in:

Research on Project, Programme and Portfolio Management

DOI:

10.1007/978-3-030-60139-3_5

Licence:

Other

Link to output in Bond University research repository.

Recommended citation(APA):

Skulmoski, G. J., Langston, C. A., Patching, A., \& Ghanbaripour, A. (2021). Sustainable Project-oriented Careers: A Conceptual Model. In R. Cuevas, C-N. Bodea, \& P. Torres-Lima (Eds.), Research on Project, Programme and Portfolio Management: Integrating Sustainability into Project Management (pp. 55-80). (Lecture Notes in Management and Industrial Engineering). Springer. https://doi.org/10.1007/978-3-030-60139-3_5

\section{General rights}

Copyright and moral rights for the publications made accessible in the public portal are retained by the authors and/or other copyright owners and it is a condition of accessing publications that users recognise and abide by the legal requirements associated with these rights.

For more information, or if you believe that this document breaches copyright, please contact the Bond University research repository coordinator. 


\title{
Chapter 5
}

\section{Sustainable Project-Oriented Careers: A Conceptual Model}

\author{
Gregory J. Skulmoski, Craig Langston, Alan Patching, Amir Ghanbaripour
}

\begin{abstract}
An area of interest for project participants is one's career. It may be as simple as looking for the next consulting contract in the Gig Economy, taking training, or thinking about the next 5-10 years to accommodate planned changes such as semi-retirement. The literature hints that project participants who take a sustainable approach to career management may enjoy better outcomes. We look at the sustainable project-oriented career concept and propose key error messages that signal career risks, such as the absence of substantial training or education within the past ten years. We examine the sustainable project-oriented career framework within the Gig Economy, including the need for periodic renewal through education and training. We review key innovations in education and training that project participants can leverage to improve career sustainability. This paper combines emerging theory with practical advice to develop sustainable project-oriented careers and to thrive in the Gig Economy and beyond.
\end{abstract}

Keywords: Sustainable project-oriented career, systematic literature review, sustainable career turbulence, sustainable career drivers

\section{G. J. Skulmoski}

Bond University, 14 University Drive, Robina, QLD, 4226, Australia,

e-mail: gskulmos@,bond.edu.au

C. Langston

Bond University, 14 University Drive, Robina, QLD, 4226, Australia,

clangsto@bond.edu.au

A. L. Patching

Bond University, 14 University Drive, Robina, QLD, 4226, Australia, apatchin@bond.edu.au

\section{A. Ghanbaripour}

Bond University, 14 University Drive, Robina, QLD, 4226, Australia, aghanbar@bond.edu.au 


\subsection{The Classic Project-Oriented Career}

Modern project management is a relatively new phenomenon despite the long history of projects throughout millennia; we did not use modern terms to describe what was happening (e.g., even though we had a project sponsor for building the pyramids, they were not called project sponsors; they were simply called pharaohs). It was not until the 20th Century that modern project management emerged as we know it today. Carayannis, Kwak, and Anbari (2005) reviewed the history of project management and traced the shift of focus from tools (e.g., PERT and Monte Carlo) to the human element (e.g., matrix organization and human resource management). We see professional organizations like the International Project Management Association form, grow and offer certifications to foster project management competence and the project-oriented career.

During this time, organizations also long relied on projects to bring new products and services to customers. Favaro (2015) distills the history of business strategy, moving from efficiency targets, through to increasing scale and improving quality, to the rise of integrated networks and ecosystems to serve customers. To achieve the strategy, organizations would plan for five to ten years and then launch a series of carefully and fully-planned projects. Many organizations transitioned to a project-oriented organization to help achieve their strategy (Gemünden, et al., 2017).

\subsubsection{Accidental Project Manager}

The project-oriented career began to evolve in this time of change. In the past, a typical career in projects began when a person joins a project team as a junior member. If they do well, then they might be promoted to a "senior" project participant (e.g., Lead Engineer). Then if they succeed, we stop them from what they do well and then give them the new role of project manager often without formal training (or they attend project scheduling software training). There is little wonder looking back that we have not equipped our project teams to succeed since many "accidental" project managers led these challenging projects (Hartman, 1999).

Professional organizations offer project-oriented certifications to address competency gaps:

- International Project Management Association (IPMA) - Certified Project Manager,

- Project Management Institute (PMI) - Project Management Professional,

- Global Association for Quality Management (GAQM) - Certified Project Director,

- British Computer Society (BCS) - Chartered Professional,

- Association for the Advancement of Cost Engineering International (AACEI) - Certified Cost Professional,

- EC Council - Project Management in IT Security.

Therefore, we see that the project-oriented career has become more formalized, requiring training and education in areas in addition to technical competence like engineering and project management tool proficiency such as budgets and schedules (Hartman, 1999). Planning a career in projects has become much more complex due to significant changes occurring in the business world. In the past, senior management would identify strategic goals, then launch a series of carefully planned projects; however, the timelines now are much more compressed, and the business environment is anything but stable. Agility, disruption, data analytics, and integration are the new business mantra (Favaro, 2015).

\subsection{The Gig Economy and Other Systemic Changes}

Long-term planning and a stable workforce were characteristics of the business environment that have long since passed. Now, we have a Gig Economy at the front end of the 4th Industrial Revolution. Indeed, Akkermans, Seibert and Mol (2018) state that a predictable career and lifetime employment with stable firms is a thing of the past. In this changing time, project-oriented people may re-examine their career path to be contributors rather than sidelined.

The Gig Economy may simply be described as temporary employment where contractors contribute to an organization's efforts through hourly or piecemeal work. For example, an independent contractor 
may join a project to set up and test a computer server, then leave the project when their contracted work is completed. Or the Gig Economy worker may be paid on a task-by-task basis such as delivery drivers (e.g., Uber drivers). Organizations now have more opportunities to hire temporary workers when required and minimize a core structure of full-time/long-term employees (Kobie, 2018).

Organizations increasingly are hiring temporary workers when needed; some in-house services are contracted to external contractors to improve organizational effectiveness and efficiency; by having non-core activities performed by contractors to allow an organization to focus on core activities. However, some organizations choose the outsourcing model to bring in highly skilled contractors to bring innovation to core areas of business (Erdogmus et al., 2018). The global demand for outsourcing in 2015 was $\$ 524.4$ billion and rose to $\$ 565$ billion two years' later. This growth has been primarily in logistics, IT (information technology) and business processing such as financial, human resource and call centers (Ikediashi \& Aigbavboa, 2019). Indeed, IT outsourcing on a global level is expected to grow; such as in 2017 when outsourcing grew by 5.7 percent in that single year (Erdogmus et al., 2018). Indeed, some industries prefer the outsourced model rather than relying on in-house services: by 2020,72 percent of all global clinical trials of pharmaceutical products is expected to be conducted by contract organizations with an annual growth rate of 6.9 annually (Wilkinson et al., 2019).

\subsubsection{The 4th Industrial Revolution: Challenges and Opportunities}

At the same time that the Gig Economy offers increased employment options, and business is more favorable to outsourcing, technology advances promise great change, opportunities, and challenges. The $4^{\text {th }}$ Industrial Revolution (also known as Industry 4.0) is the continuation of step-changes to business beginning with the $1^{\text {st }}$ Industrial Revolution (see Figure 1). We have progressed by applying steam, electricity and basic information and computer technologies to production. Now we see disruptive technologies being applied to virtual and physical activities on a global scale to allow organizations to cooperate to deliver new products and customizations in ways never before imagined possible or even demanded by consumers (Avis, 2018).

Disruptive technologies are those resources or tools used to produce things (e.g., artificial intelligence) or a finished product with disruptive characteristics (e.g., self-driving car). Other disruptive technologies include blockchain, gene sequencing, large-scale energy storage, building information modeling, nanotechnology, biotechnology, quantum computing, robotics, the Internet of Things, and other transformative technologies that can have dual potentialities to help and/or harm (Schwab, 2016). For example, we may see ingestible robots that repair injuries from within, and we may see jobs displaced by these disruptive technologies. Indeed, a recent survey of 1,730 project participants reported that 91 percent of them were impacted by disruptive technologies (PMI, 2018a). Indeed, there are technical "pessimists" who predict severe net job loss due to these disruptive technologies with significant impacts on society (Schwab, 2016). How is business impacted beyond the common challenges of global competition, shorter production cycles, and consumer demand for customization? What is the impact to project participants? 
Fig. 1: $4^{\mathrm{TH}}$ Industrial Revolutions (adapted from 123RF, 2019)

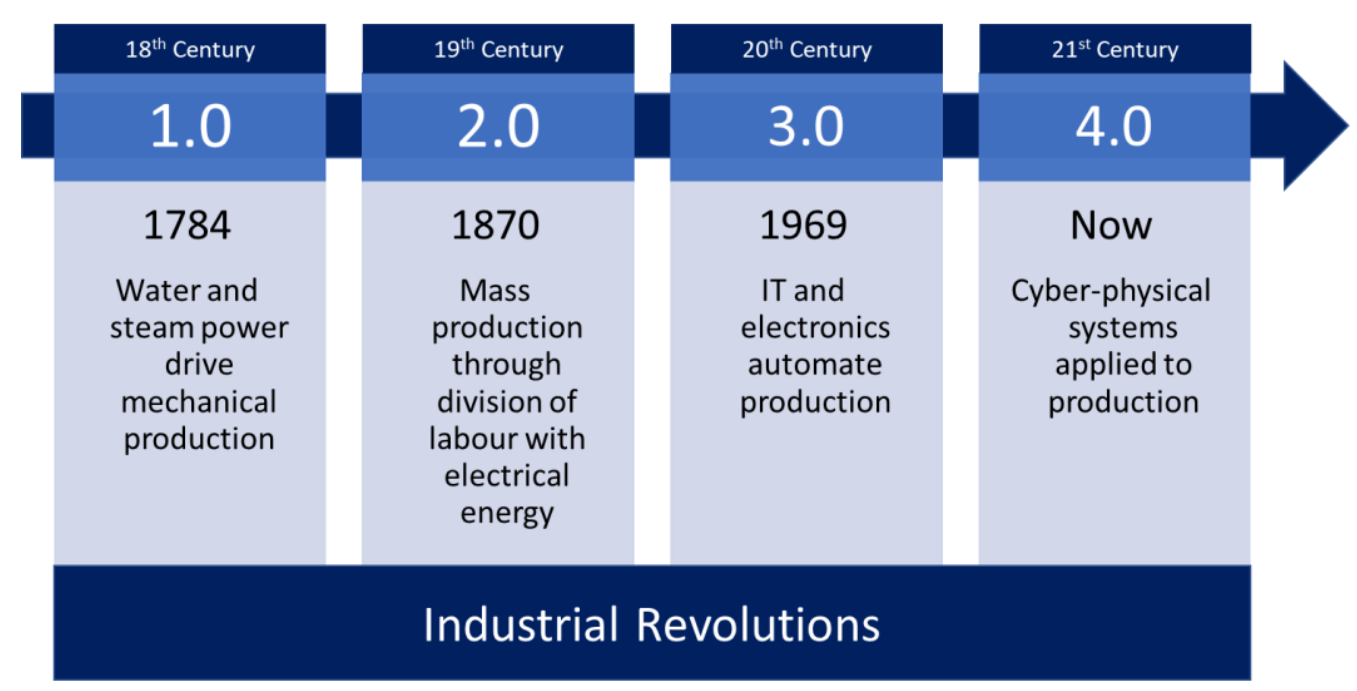

The $4^{\text {th }}$ Industrial Revolution will likely impact the business by changing consumer expectations (e.g., sustainability), product enhancement (e.g., add digital capabilities to products), collaborative innovation (e.g., work with others), and the way organizations form and organize (Schwab, 2016). The news media is ripe with businesses failing thanks to disruptive technologies: we know about the drastic decline of Kodak, Blackberry, and Blockbuster. Technology laggards are more likely to lack a mature digital business strategy, are risk-averse, and technology adoption is a low priority (PMI, 2018a). Many organizations may struggle against competitors who are agile and innovative, and harness global digital platforms for research, development, marketing, sales and distribution to outperform digital laggards (Schwab, 2016). Unfortunately, even if organizations have a digital strategy to deliver innovation, approximately one in 10 organizations fail to deliver that strategy (PMI, 2018a). That is, even if an organization has a well-thought-out strategy delivered through innovation, they are likely to struggle to deliver that strategy through a project approach. But it is not organizations that deliver - it is people who deliver innovations through projects to achieve the strategy. Therefore, Gartner (2019) recommends skill renewal to remain competitive.

\subsubsection{New Project-Oriented Opportunities}

Within these changes - Gig Economy, globalization, outsourcing, disruptive technologies, $4^{\text {th }}$ industrial revolution, and more - project-oriented workers who desire to succeed, may think strategically about their careers. What does the project-oriented work forecast look like? Are there jobs in project management despite job loss predictions associated with the $4^{\text {th }}$ Industrial Revolution? Crawford, French and Lloyd-Walker (2013, p. 1175) state that "a growing percentage of the Australian workforce is employed in project-based or project-oriented organisations, leading to the claim that Australia is a project-based economy". A recent study found that global organizations (chiefly in the financial services, industrial and manufacturing, consumer services, government and non-profit, and retail and hospitality sectors) involved in delivering innovative projects rank the technical talent shortage as their top risk to strategy success (Gartner, 2019). Indeed, this shortfall is validated in a PMI (2017) study that also looked at the supply and demand of project-oriented people and forecasted a talent shortage:

- By 2027, organizations will need 87.7 million people in project-oriented roles;

- The talent gap could result in a loss of $\$ 207.9$ billion in GDP through 2027;

- On an annual basis, organizations will need to fill 2.2 million project-oriented jobs each year through to 2027.

Thus, while there could be an overall net job loss, there appear to be opportunities in technical areas, and especially in project management for people with the right skills. Technical proficiency ("Project 
Management Technical Quotient" - PMTQ) with disruptive technologies is an emerging project-oriented skillset: the ability to select, modify, manage and integrate technologies to solve problems and add value to specific projects (PMI, 2019). Those with PMTQ competencies have three distinctive characteristics in addition to long-standing competencies like soft skills, project management tools and process expertise in traditional and adaptive delivery methods like Agile, and business strategy skills (PMI, 2019):

- Curiosity: they welcome new ideas and ways of doing things wherever it may lie on the low to high technology continuum. They have an open mind, tempered with some skepticism.

- Inclusive Leadership: they look after not only their team but their team's resources such as technology and robots.

- Future-Proof Talent Pool: they recruit and nurture those who embrace these digital skills, and keep up with trends and adapt their own skill sets accordingly; there is a regular renewal of skills.

When a project-oriented person has these updated skills, including PMTQ, then they are more likely to find and keep jobs in project-oriented organizations (PMI 2018b) or to deliver value through an outsourcing arrangement. This raises the question: what can be found in the project-oriented literature and research?

\subsection{Sustainable Project-Oriented Career}

To learn more about sustainable careers, we follow a systematic literature review process that involves two steps: plan the literature review process, then follow the literature review plan (Calderón, Ruiz, 2015). We conduct a Boolean search of key career sustainable terms (see Table 1) and you searched across over 170 databases, including the following electronic databases such as ISIWeb of Science, Scopus, and SpringerLink. After searching the entire databases (e.g., everywhere), we narrow our Boolean search to filter in those articles from peer-reviewed journals. We then search only in the title of the publications of peer-reviewed journals.

Table 1 Search terms

\begin{tabular}{|l|c|}
\hline Search Actions & Results Returned \\
\hline 1. Search "sustainable career" in EVERYWHERE & 589 \\
\hline 2. Filter for results from only PEER-REVIEWED JOURNALS & 302 \\
\hline 3. Search "sustainable career" in TITLE & 12 \\
\hline
\end{tabular}

We follow the Calderón and Ruiz (2015) systematic literature review process and applied inclusion and exclusion criteria (see Table 2) to guide the quality of our review. One might be surprised that only 12 journal papers were found with the term "sustainable career" in their titles.

Table 2 Inclusion and exclusion criteria

\begin{tabular}{|l|l|}
\hline \multicolumn{2}{|l|}{ Criteria } \\
\hline Inclusion Criteria & $\begin{array}{l}\text { Publications that are related to career sustainability } \\
\text { Publications that are related to elements of the Sustainable Project-Oriented Career } \\
\text { Publications that were peer-reviewed }\end{array}$ \\
\hline Exclusion Criteria & $\begin{array}{l}\text { Publications that are did not have full-text available } \\
\text { Publications that were not in English } \\
\text { Publications that incidentally referred to elements of the Sustainable Project-Oriented Career }\end{array}$ \\
\hline
\end{tabular}

We then read the publications identified in Step 2, Table 1. 
At some point in our careers, we were hired or brought onto a project team; we had the necessary competencies to add value. However, with time comes unpredictability, change, and new technology; not all project participants have kept up with advances and are at risk of not being selected for future projects if they do not have the right skills (e.g., their PMTQ is weak). What has to happen for career continuity? Is there such a thing as a sustainable project-oriented career (SPOC)?

Sustainable careers are becoming an increasingly pronounced concern for many as evidenced in the recent growth of research papers in scientific journals and conferences (De Vos et al., 2018). Indeed, even the meaning of career is in flux as we see more workers adopt a subjective view of career success rather the more traditional view of career success through hierarchical progression (De Vos, Van Der Heijden and Ijm, 2017). One emerging career sustainability model incorporates agency theory from psychology (the individual obeys the organization in exchange for the organization taking responsibility for their actions); it brings together the dimensions and indicators of career sustainability (De Vos et al., 2018). The De Vos career sustainability model begins with the concept of time in that sustainability is related to what happens over one's career to protect and foster human and career development. We have modified the model to substitute a project-oriented career occurring over time. It is over time that we can better assess sustainability rather than during a discrete moment of analysis. We have modified this model to specifically explain a project-oriented approach, rather than a psychological approach to career sustainability.

The key modification to this career sustainability model (see Figure 2) is to replace the individual's agency modeling perspective with a person in a project-oriented career, working over time on a series of projects. In project-oriented organizations, a person may temporarily join an organization to perform project work, and then leave the organization upon completion of that work. However, some join an organization, and then stay for a series of projects, and then leave the organization (Huemann, Keegan and Turner, 2007). It is this concept of a person working in a series of projects that displaces psychological concepts related to career sustainability.

Fig. 2: Sustainable Project-Oriented Career

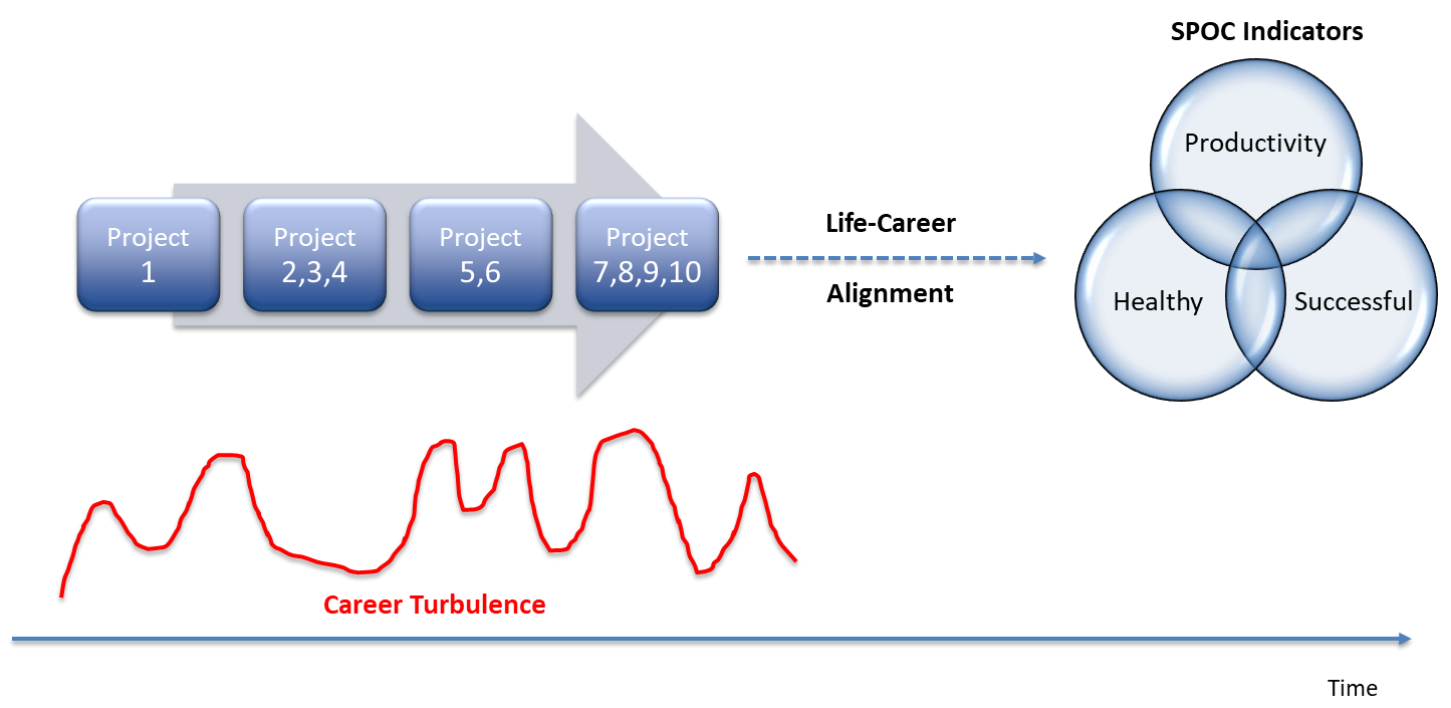

When one has a project-oriented career, and one works in a series of projects, the notion of career sustainability may eventually be considered. Career sustainability is indicated by three elements:

i) Productivity, where the individual performs successfully in their current role as well as having a high potential for future employability. New joiners and existing workers may need to learn new skills to complete tasks.

ii) ii) Health, where a holistic and comprehensive view of health fits with the demands of one's career. With time, health can change: workers begin jobs and initially meet the 
demands of a job, but with age, one may be less capable (e.g., a job in construction where it becomes more difficult with age to complete tasks requiring manual labor).

iii) Happiness, where the subjective elements relate to holistic satisfaction and feeling successful in one's career - past and present, and one's life outside the career occur.

An important concept is a fluid fit between these three career sustainability indicators: all three may be in flux and impact each other over time (De Vos et al., 2018). Thus, a project participant works in a series of projects over their career, and if the person has the right mix of success, health and productivity over time, that person has had a sustainable career.

\subsubsection{Sustainable Career Turbulence}

During one's career, there is the notion that chance events (positive or negative) can occur that alter career trajectory; Akkermans, Seibert and Mol (2018) refer to this as career shocks. The worker has control over some shocks like a decision to get pregnant that can impact their career. However, there are some shocks that the worker has less control such as when a person is made redundant or promoted to a position with more responsibility requiring more effort. These career shocks vary in intensity (moderate to severe), valence (positive or negative effects), frequency, and duration (De Vos et al., 2018). These career shocks may also be predictable or unpredictable, as well as originate from multiple sources such as geopolitical, environmental, organizational, interpersonal and family-oriented (Akkermans, Seibert \& Mol, 2018). Given enough time, most working people face a career shock; how a person reacts or indeed, plans for the career shock, impacts career sustainability. In this paper, we use the term "turbulence" rather than shock, since we can often avoid the ill-effects of turbulence, whereas shocks imply less control. Therefore, we substitute career turbulence for career shocks in our model. In Table 3, we identify examples of career turbulence from our systematic review of the literature.

Table 3 Turbulence in sustainable careers

\begin{tabular}{|c|c|c|c|c|}
\hline Author & Year & Empirical & Focus & Turbulence \\
\hline lles & 1997 & Opinion & $\begin{array}{l}\text { Sustainable career development of } \\
\text { high-potential employees }\end{array}$ & $\begin{array}{l}\text { Acceleration of organizational restructuring, downsizing, } \\
\text { outsourcing and delayering }\end{array}$ \\
\hline Stronach & 2010 & $\mathrm{~N}=14$, mixed & $\begin{array}{l}\text { Career sustainability of Indigenous } \\
\text { Australian boxers }\end{array}$ & Lack of mentoring \\
\hline Asuquo & 2013 & $\mathrm{~N}=210$, surveys & $\begin{array}{l}\text { How to build a sustainable career in } \\
\text { environmental anthropology }\end{array}$ & Not staying connected with your community of practice \\
\hline De Vos & 2017 & Opinion & Career sustainability in general & $\begin{array}{l}\text { Longer careers due to delayed retirement, shorter and less } \\
\text { predictable sequence of jobs, more alternative modes of } \\
\text { work (e.g., part-time, contracting, etc.), fading boundaries } \\
\text { between work and non-work, new ways of working, per- } \\
\text { sonal career development accountability, and rise of sub- } \\
\text { jective career success }\end{array}$ \\
\hline Van Driel & 2017 & $\mathrm{~N}=18$, interviews & $\begin{array}{l}\text { Retaining Australia General Practi- } \\
\text { tioner research leaders }\end{array}$ & $\begin{array}{l}\text { Switching institutions, working in isolation, work-life bal- } \\
\text { ance, research as a hobby, lack of professional standing, } \\
\text { managing dual careers, lack of research funding, low remu- } \\
\text { neration }\end{array}$ \\
\hline Fournier & 2018 & $\mathrm{~N}=61$, interviews & Job loss of older Canadian workers & $\begin{array}{l}\text { Globalization, increasing competition, more technology, un- } \\
\text { stable ties to work }\end{array}$ \\
\hline McDonald & 2018 & Opinion & Creating sustainable careers & $\begin{array}{l}\text { Automation, reduction of permanent jobs and a shift to tem- } \\
\text { porary, contract and other forms of work, advanced tech- } \\
\text { nology, perceived work insecurity, job precariousness }\end{array}$ \\
\hline Venkatraman & 2018 & Opinion & $\begin{array}{l}\text { Improving career outcomes for tech- } \\
\text { nical education students }\end{array}$ & New technologies as a result of $4^{\text {th }}$ Industrial Revolution \\
\hline
\end{tabular}




\begin{tabular}{|c|c|c|c|c|}
\hline Barthauer & 2019 & $\mathrm{~N}=385$, surveys & $\begin{array}{l}\text { Career sustainability of German sci- } \\
\text { entists }\end{array}$ & Role misfit, burnout \\
\hline Chin & 2019 & $\begin{array}{l}\mathrm{N}=2, \text { case } \\
\text { studies }\end{array}$ & $\begin{array}{l}\text { Career sustainability of Chinese man- } \\
\text { ufacturing workers }\end{array}$ & New technologies, new business models \\
\hline Heslin & 2019 & Opinion & $\begin{array}{l}\text { Role of learning mode in a sustaina- } \\
\text { ble career }\end{array}$ & Under-employment, lay-offs, unemployment \\
\hline Jacobs & 2019 & $\mathrm{~N}=1874$, surveys & $\begin{array}{l}\text { Role of networking for European free- } \\
\text { lancers }\end{array}$ & $\begin{array}{l}\text { Organizations increasingly shift career development re- } \\
\text { sponsibilities to employees and other workers }\end{array}$ \\
\hline Mutter & 2019 & $\mathrm{~N}=21$, interviews & $\begin{array}{l}\text { Global mobility and the career of } \\
\text { stay-at-home partner }\end{array}$ & $\begin{array}{l}\text { Career planning and development procrastination, career } \\
\text { coordination challenges with one's partner }\end{array}$ \\
\hline Peters & 2019 & $\mathrm{~N}=98$, surveys & $\begin{array}{l}\text { Effects of age-based stereotyping on } \\
\text { older supermarket workers }\end{array}$ & Negative stereotyping of older workers \\
\hline Spooner & 2019 & $\mathrm{~N}=65$, interviews & $\begin{array}{l}\text { Influence of training on career inten- } \\
\text { tions of future General Practitioners }\end{array}$ & $\begin{array}{l}\text { Rising workloads, isolation, ill-prepared to manage periph- } \\
\text { ery activities to one's profession (e.g., financial manage- } \\
\text { ment) }\end{array}$ \\
\hline Stauer & 2019 & $N=5205$, surveys & $\begin{array}{l}\text { Career sustainability of Belgian work- } \\
\text { ers across the lifespan }\end{array}$ & Finding and retaining work \\
\hline Xiao & 2019 & $\mathrm{~N}=614$, surveys & $\begin{array}{l}\text { Effects of stock ownership on career } \\
\text { development in China }\end{array}$ & Stress due to changes \\
\hline
\end{tabular}

Thus, the Sustainable Project-Oriented Career model has the project participant working in a projectoriented organization either as a contractor or as an internal employee. This person works on a series of projects over time, and this is called a project-oriented career. During this career, there are most likely career shocks (positive and negative, that vary in intensity) that face the project participant. If the person makes the right decisions, then there will be a fit between the career and the career sustainability indicators of being successful, healthy and productive will be positive. If the person does not respond appropriately to career shocks, then a sustainable project-oriented career is in jeopardy. Increasingly, a self-directed or "protean career" is the responsibility of the individual rather than the organization (Akkermans, Seibert \& Mol, 2018).

When we reviewed general literature for elements of turbulence, we find potential examples of career turbulence that could cause challenges for project-oriented people:

- The globalization of work and changes to how work is structured,

- Organizations reducing the amount of responsibility for workers' careers,

- Career planning and development procrastination,

- Increasing personal competency and threshold skill deficits, and

- Increasing stress and a work-life imbalance.

The literature also reveals things people should do who have sustainable careers; we refer to these enablers as sustainable career drivers.

\subsubsection{Sustainable Career Drivers}

There are three key areas of response a person can take to improve the probability they have a sustainable project-oriented career. Repeatedly, the notion of career renewal is highlighted as critical to a sustainable career (Adams, 2006; Valcour, 2013; Mayrhofer, 2016; Mcdonald and Hite, 2018). It has been long recognized that individuals might complete formal training or education in areas of demand (especially future demand) so that one's skills align with the needs of the organization (Skulmoski, 2001). Second, one's career is more likely to become sustainable if one is flexible and adaptable to new opportunities; simply, the more one can do, the more opportunities there will be to choose, resulting in career continuity (Valcour, 2013; Mcdonald and Hite, 2018). Finally, building upon worklife balance research, career sustainability is more likely if the career is integrated with one's home 
life, the community and society (Adams, 2006; Osif, 2009; Overbaugh, 2011; Valcour, 2013; Witzig $\&$ Smith, 2019). We reviewed the literature for elements related to our Sustainable Project-Oriented Career model and uncovered potentially applicable sustainable career drivers (see Table 4).

Table 4 Sustainable career drivers

\begin{tabular}{|c|c|c|c|c|}
\hline Author & Year & Empirical & Focus & Career Sustainability Drivers \\
\hline Bennett & 2009 & $\mathrm{~N}=239$, surveys & $\begin{array}{l}\text { Career sustainability for professional } \\
\text { musicians and dancers }\end{array}$ & $\begin{array}{l}\text { Develop small business skills (including marketing), teaching, adopt } \\
\text { new technologies }\end{array}$ \\
\hline Murray & 2009 & Opinion & Improving the Australian political class & $\begin{array}{l}\text { Improve career sustainability through continuous training and pro- } \\
\text { fessionalism }\end{array}$ \\
\hline Singhvi & 2010 & Opinion & Building a sustainable career in science & Network, review papers, submit grants \\
\hline Stronach & 2010 & $\mathrm{~N}=14$, mixed & $\begin{array}{l}\text { Career sustainability of Indigenous } \\
\text { Australian boxers }\end{array}$ & Pursue training and or education for renewal, work with mentors \\
\hline Hall & 2012 & $\mathrm{~N}=73$, surveys & $\begin{array}{l}\text { Career success while sustaining per- } \\
\text { sonal and family well-being }\end{array}$ & Understand that career success can be personal and subjective \\
\hline Herman & 2012 & $N=38$ & $\begin{array}{l}\text { Motherhood and sustainable career in } \\
\text { science, engineering, and technology }\end{array}$ & $\begin{array}{l}\text { Develop a sense of entitlement for reduced working hours without } \\
\text { forfeiting one's career }\end{array}$ \\
\hline Watson & 2012 & $\mathrm{~N}=36$, interviews & $\begin{array}{l}\text { Career sustainability of Victoria musi- } \\
\text { cians }\end{array}$ & $\begin{array}{l}\text { Develop a companion career related to the primary career, work } \\
\text { with a mentor }\end{array}$ \\
\hline Asuquo & 2013 & $\mathrm{~N}=210$, surveys & Employability of Nigerian youth & $\begin{array}{l}\text { Learn continuously, network, be a team-player, be persistent, plan, } \\
\text { take risks, be optimistic, be flexible }\end{array}$ \\
\hline Siegel & 2013 & Opinion & $\begin{array}{l}\text { Career sustainability of orthopaedic } \\
\text { surgeons }\end{array}$ & $\begin{array}{l}\text { Manage yourself and your business, develop good relationships with } \\
\text { vendors, maintain an active status with your medical licenses }\end{array}$ \\
\hline Montgomery & 2014 & Opinion & $\begin{array}{l}\text { Mentoring graduate students and junior } \\
\text { faculty }\end{array}$ & Work with a mentor over one's total career \\
\hline Dahl & 2015 & $\mathrm{~N}=10$, interviews & $\begin{array}{l}\text { Career sustainability of Swedish Lei- } \\
\text { sure-time teachers }\end{array}$ & $\begin{array}{l}\text { Develop profession-specific threshold competencies: developmental } \\
\text { and group psychology, knowledge about social interaction, leader- } \\
\text { ship and conflict management }\end{array}$ \\
\hline Ochs-Balcom & 2015 & Opinion & $\begin{array}{l}\text { Career sustainability of young Ameri- } \\
\text { can cancer researchers }\end{array}$ & Network broadly, develop cross-disciplinary collaborations \\
\hline Beeching & 2016 & $\mathrm{~N}=33$, interviews & $\begin{array}{l}\text { Career sustainability for professional } \\
\text { musicians }\end{array}$ & Know your audience, role flexibility, perform multiple roles, \\
\hline Hlanganipai & 2016 & $\mathrm{~N}=85$, surveys & $\begin{array}{l}\text { Role of training and development in } \\
\text { South African retail and wholesale } \\
\text { managers }\end{array}$ & Plan training and development for your career \\
\hline Rosenblum & 2016 & Opinion & $\begin{array}{l}\text { Professional identity and the clinician- } \\
\text { scientist }\end{array}$ & $\begin{array}{l}\text { Have certainty of personal values, ambitions, abilities; develop resili- } \\
\text { ence, self-esteem and self-perceived competence; have tolerance } \\
\text { for ambiguity and complexity; have the ability to manage complexity; } \\
\text { work with a mentor; pursue life-career balance }\end{array}$ \\
\hline De Vos & 2017 & Opinion & Career sustainability in general & $\begin{array}{l}\text { Plan personal career development rather than vertical advance- } \\
\text { ment; manage work and non-work activities to minimize spillover; } \\
\text { develop career competencies (self-awareness, self-management, } \\
\text { etc.). }\end{array}$ \\
\hline Van Driel & 2017 & $\mathrm{~N}=18$, interviews & $\begin{array}{l}\text { Retaining Australia General Practitioner } \\
\text { research leaders }\end{array}$ & $\begin{array}{l}\text { Develop mentorships, alliances and, collaborations; take leadership } \\
\text { training }\end{array}$ \\
\hline De Vos & 2018 & Opinion & Career sustainability model & Be proactive \\
\hline
\end{tabular}




\begin{tabular}{|c|c|c|c|c|}
\hline Ko & 2018 & Opinion & $\begin{array}{l}\text { Career development for general sur- } \\
\text { geons }\end{array}$ & Be a competent generalist, but also specialize (dual careers) \\
\hline Pajic & 2018 & $N=314$, surveys & Hungarian nurses career adaptability & Have a proactive and conscientious personality; be adaptable \\
\hline Taponen & 2018 & $N=2613$, surveys & $\begin{array}{l}\text { Career employment status and } \\
\text { changes to due to asthma }\end{array}$ & Get advice from a counselor; manage your asthma treatment \\
\hline Barthauer & 2019 & $N=385$, surveys & $\begin{array}{l}\text { Career sustainability of German scien- } \\
\text { tists }\end{array}$ & Develop a long-term focus and consider career mobility \\
\hline Chin & 2019 & $\begin{array}{l}\mathrm{N}=2 \text {, case } \\
\text { studies }\end{array}$ & $\begin{array}{l}\text { Career sustainability of Chinese manu- } \\
\text { facturing workers }\end{array}$ & Become resourceful, flexible and integrative, plan for renewal \\
\hline Frie & 2019 & $N=10$, interviews & How "flexperts" renew their expertise & $\begin{array}{l}\text { Gain the ability to make sense of new knowledge and skills, and } \\
\text { have confidence for mastery }\end{array}$ \\
\hline Goodwin & 2019 & $N=28$ & $\begin{array}{l}\text { Developing self-efficacy and career op- } \\
\text { timism in Australian creative industries }\end{array}$ & Join a community of practice \\
\hline Heslin & 2019 & Opinion & $\begin{array}{l}\text { Role of learning mode in a sustainable } \\
\text { career }\end{array}$ & $\begin{array}{l}\text { Be in the learning mode (always learning); apply self-directed and } \\
\text { self-regulated learning }\end{array}$ \\
\hline Hirschi & 2019 & $\mathrm{~N}=2679$, surveys & $\begin{array}{l}\text { Sustainable careers and the impact of } \\
\text { nonwork }\end{array}$ & $\begin{array}{l}\text { Develop professional traits: agreeableness, extraversion and open- } \\
\text { ness; and motives: curiosity and an interest in new experiences }\end{array}$ \\
\hline Jacobs & 2019 & $N=1874$, surveys & $\begin{array}{l}\text { Role of networking for European free- } \\
\text { lancers }\end{array}$ & Network proactively; take ownership for one's career \\
\hline Kelly & 2019 & $N=280$, surveys & $\begin{array}{l}\text { Role of leisure seriousness and sus- } \\
\text { tainable careers }\end{array}$ & $\begin{array}{l}\text { Engage in serious leisure; network while participating in leisure ac- } \\
\text { tivities }\end{array}$ \\
\hline Kotecha & 2019 & Opinion & $\begin{array}{l}\text { General practitioner career sustainabil- } \\
\text { ity advice }\end{array}$ & $\begin{array}{l}\text { Learn continuously; join a community of practice; lead professional } \\
\text { conversations; manage your well-being; shape the future (innovation } \\
\text { and research) }\end{array}$ \\
\hline Merritt & 2019 & Opinion & $\begin{array}{l}\text { Building capacity of early career re- } \\
\text { searchers }\end{array}$ & $\begin{array}{l}\text { Develop threshold competencies (e.g., presentation skills, team- } \\
\text { work, etc.) }\end{array}$ \\
\hline Mutter & 2019 & $\mathrm{~N}=21$, interviews & $\begin{array}{l}\text { Global mobility and the career of stay- } \\
\text { at-home partner }\end{array}$ & $\begin{array}{l}\text { Negotiate and plan for career development; pursue flexible work } \\
\text { agreements }\end{array}$ \\
\hline Olsson & 2019 & $N=15$, interviews & $\begin{array}{l}\text { Specialty choice of Swedish medical } \\
\text { doctors }\end{array}$ & $\begin{array}{l}\text { Be invited into your community of practice; fit in and contribute to } \\
\text { your organization }\end{array}$ \\
\hline Pajic & 2018 & $N=314$, surveys & Hungarian nurses career adaptability & Have a proactive and conscientious personality; be adaptable \\
\hline Suhairom & 2019 & $\mathrm{~N}=9$, interviews & $\begin{array}{l}\text { Sustainable careers for culinary profes- } \\
\text { sionals }\end{array}$ & $\begin{array}{l}\text { Develop career-specific competencies (creative culinary), general } \\
\text { competencies (business acumen, situational adaptability, self-devel- } \\
\text { opment, strategic positioner, virtual collaboration, openness, emo- } \\
\text { tional stability, agreeableness, conscientiousness, extroversion, } \\
\text { sense of worth, and relationship management }\end{array}$ \\
\hline Bozionelos & $\begin{array}{l}\text { In } \\
\text { Press }\end{array}$ & $\mathrm{N}=334$, surveys & $\begin{array}{l}\text { Career sustainability of Hong Kong } \\
\text { salespeople }\end{array}$ & Become a continuous learner, open and adaptable; manage change \\
\hline Chudzikowski & $\begin{array}{l}\ln \\
\text { Press }\end{array}$ & $\mathrm{N}=34$, interviews & $\begin{array}{l}\text { Career sustainability of international } \\
\text { management consultants }\end{array}$ & $\begin{array}{l}\text { Conform and align early with one's organization; take ownership for } \\
\text { own's career }\end{array}$ \\
\hline
\end{tabular}

Therefore, a sustainable career is more likely if one takes time for periodic renewal, one is flexible and adaptable to leverage new opportunities, and one's career is holistically integrated to achieve an acceptable work-life balance trajectory. We find in general career research literature, career sustainability drivers help guide workers and human resource management professionals to build and maintain sustainable careers. But what about sustainable careers in project management? 


\subsubsection{Sustainable Project-Oriented Careers}

We systematically review the six, project management-related journals and search everywhere for the term "sustainable career," and we find only one result (see Table 5). We also search for the term "career" everywhere, and then again, but only in the title; and find that career sustainability is a new term in the project management-oriented literature. We review these papers for their relevance to sustainable careers. We learnt that many of the results were due to the authors using the term "career" publication biography, rather than somehow relating to their research.

Table 5 Sustainable careers in project management literature

\begin{tabular}{|l|c|c|c|}
\hline Journal & $\begin{array}{c}\text { Sustainable Career } \\
\text { Everywhere }\end{array}$ & $\begin{array}{c}\text { Career } \\
\text { Everywhere }\end{array}$ & $\begin{array}{c}\text { Career } \\
\text { in Title }\end{array}$ \\
\hline International Project Management Journal & 0 & 397 & 25 \\
\hline Project Management Journal & 1 & 279 & 0 \\
\hline Project Management Research and Practice & 0 & 4 & 0 \\
\hline Modern Project Management & 0 & 1 & 0 \\
\hline International Journal of Construction Management & 0 & 11 & 0 \\
\hline Journal of Engineering, Project and Production Management & 0 & 10 & 3 \\
\hline
\end{tabular}

Again, we find that within the project management literature, there were hints of sustainable career turbulence (see Table 6) and drivers (see Table 7).

Table 6 Turbulence in project-oriented sustainable careers

\begin{tabular}{|l|l|l|l|l|}
\hline Author & Year & Empirical & \multicolumn{1}{|c|}{ Project Mgmt Focus } & \multicolumn{1}{|c|}{ Turbulence } \\
\hline Bredin & 2013 & $\mathrm{~N}=10$, case study & $\begin{array}{l}\text { Project managers and career models } \\
\text { of Swedish project-oriented firms }\end{array}$ & Lack of job rotation to increase competency \\
\hline Crawford & 2013 & $\mathrm{~N}=9$, interviews & Project career paths in Australia & Rise of contract work \\
\hline Havermans & 2019 & $\mathrm{~N}=21$, interviews & $\begin{array}{l}\text { Explore the motivation and experi- } \\
\text { ence of becoming a project manager }\end{array}$ & $\begin{array}{l}\text { Frustrating processes, project administration, stress from } \\
\text { conflict and work overload, changing work conditions, ac- } \\
\text { countability without authority, politics }\end{array}$ \\
\hline Huemann & 2019 & $\mathrm{~N}=20$, Interviews & $\begin{array}{l}\text { Project manager career development } \\
\text { and line manager relationships }\end{array}$ & $\begin{array}{l}\text { Lack of project manager, career development support from } \\
\text { line managers }\end{array}$ \\
\hline
\end{tabular}

Table 7 Project-oriented sustainable career drivers

\begin{tabular}{|l|l|l|l|l|}
\hline Author & Year & Empirical & Project Mgmt Focus & \multicolumn{1}{c|}{ Career Sustainability Drivers } \\
\hline Ahsan & 2013 & $\begin{array}{l}\mathrm{N}=795, \text { content } \\
\text { analysis }\end{array}$ & $\begin{array}{l}\text { Comparative analysis of competen- } \\
\text { cies in job advertisements }\end{array}$ & $\begin{array}{l}\text { Have the necessary competencies called for in the job ad- } \\
\text { vertisement }\end{array}$ \\
\hline Bredin & 2013 & $\mathrm{~N}=10$, case study & $\begin{array}{l}\text { Project managers and career models } \\
\text { of Swedish project-oriented firms }\end{array}$ & $\begin{array}{l}\text { Work for organizations that have career models to guide } \\
\text { project managers' career development; project manage- } \\
\text { ment training programs; offer organizational career devel- } \\
\text { opment opportunities; and have a talent management pro- } \\
\text { gram to build project management capacity; build personal } \\
\text { project management competencies }\end{array}$ \\
\hline
\end{tabular}




\begin{tabular}{|c|c|c|c|c|}
\hline Crawford & 2013 & $\mathrm{~N}=9$, Interviews & Project career paths in Australia & $\begin{array}{l}\text { Show movement from simpler to more complex projects; } \\
\text { work within collaborative and innovative project structures; } \\
\text { engage with mentors }\end{array}$ \\
\hline McKevitt & 2017 & $\mathrm{~N}=207$, surveys & $\begin{array}{l}\text { Work identify and career satisfaction } \\
\text { of IT project managers }\end{array}$ & $\begin{array}{l}\text { Develop a high project management identity that can lead } \\
\text { to career satisfaction }\end{array}$ \\
\hline Gruden & 2018 & $\mathrm{~N}=69$, surveys & $\begin{array}{l}\text { Influence of behavioral competencies } \\
\text { on project performance }\end{array}$ & Develop behavioral competencies \\
\hline Chen & 2019 & $\begin{array}{l}\mathrm{N}=228, \text { surveys } \\
\mathrm{N}=10 \text {, interviews }\end{array}$ & $\begin{array}{l}\text { Identify relevant project management } \\
\text { competencies for Chinese construc- } \\
\text { tion companies }\end{array}$ & Follow a career path of increasing responsibility \\
\hline Havermans & 2019 & $\mathrm{~N}=21$, interviews & $\begin{array}{l}\text { Explore the motivation and experi- } \\
\text { ence of becoming a project manager }\end{array}$ & $\begin{array}{l}\text { Have the necessary competencies to successfully manage } \\
\text { the project; be aware that there may be conflicting expecta- } \\
\text { tions of superiors }\end{array}$ \\
\hline Huemann & 2019 & $\mathrm{~N}=20$, Interviews & $\begin{array}{l}\text { Project manager career development } \\
\text { and line managers }\end{array}$ & $\begin{array}{l}\text { Work with a mentor; have a buddy; and, participate in a } \\
\text { community of practice }\end{array}$ \\
\hline Wen & 2019 & $\mathrm{~N}-163 \mathrm{~m}$ survey & $\begin{array}{l}\text { Project manager's competencies in } \\
\text { the project closing phase }\end{array}$ & Get feedback at closeout as an input to career planning \\
\hline
\end{tabular}

When one reviews the project management literature, research and opinion articles about sustainable careers in project management do not exist; however, there is useful information related to sustainable project-oriented career turbulence and drivers. We believe that a perceptive project participant may see signs that their project-oriented career is unsustainable: that is, there may be "error messages" that one's career is in trouble.

\subsection{Error Messages Your Career is in Trouble}

We offer error messages as indicators that one's career may not be sustainable. Hartman (2000) developed a series of project management error messages designed to alert the project manager that something is wrong in their project. While no one sustainable project-oriented career error message may be the "nail in the coffin," a sustainable project-oriented career is in jeopardy as error messages accumulate. After our literature review analysis, we have categorized these error messages into i) renewal opportunities, ii) adaptability, and iii) holistic integration (e.g., work-life balance).

\subsubsection{Error Messages: Lack of Flexibility}

- Assigned the same types of projects time after time,

- Haphazard and infrequent networking to uncover new opportunities,

- Did not get the promotion, job or contract,

- Shut out from normal activities (e.g., not invited or contracting meetings),

- Works on the same aspects of PM on all projects (scheduling for example, without cross-fertilization of competence in other knowledge areas),

- Does not contribute to professional activities outside the workplace,

- Does not promote the company he or she is working for in meetings or conferences outside of the organization,

- Does not update the work procedures according to the lessons learned or from reading new PM literature,

- Can only work with particular types of people,

- Not open to new ideas coming from subordinates or the project team.

These types of error messages may indicate that your career may benefit from being open to new opportunities to expand career flexibility. 


\subsubsection{Error Messages: Lack of Holistic Integration}

- Clinically depressed,

- No longer exercise as often as you would like,

- Unplanned career absences,

- High annual leave balance,

- Does not take advantage of employer-offered stress avoidance or stress management schemes or employee assistance programs,

- Regularly works more than 50 hours per week,

- Regularly works at home after a full day of work for more than an hour or more than two evenings a week,

- Consistently works at least half a day on weekends for more than one weekend a month,

- Thinks about the undesirable things that occurred in the workplace,

- Stressed about the risks that are extremely unlikely to happen.

These types of error messages may indicate that your career may benefit from more work-life balance to have a more holistic integration.

\subsubsection{Error Messages: Lack of Renewal Opportunities}

- Long-time since your last formal class that had an assessment component,

- Infrequent professional development other than mandatory learning requirements (e.g., Fire Safety),

- Unfamiliar with Adaptive Project Management methods (Agile, Scrum, \#NoProjects, Kanban, Lean),

- Curriculum vitae is out of date,

- Lack of professional institution membership (e.g., IPMA, PMI, etc.),

- Infrequently reads journals or magazines from your industry,

- Headhunters seldom contact you,

- Infrequent and irregular online professional social network participation (i.e., LinkedIn, ProjectManagement.com, GanttHead.com, etc.),

- Unfamiliar with emerging PM computer/ mobile applications. (i.e., Slack, Monday, WorkflowMax, Wrike, Trello, Mavenlink, Asana, etc.).

These types of error messages may indicate that a sustainable project-oriented career may benefit from an intervention such as renewal. At the same time that we see disruption and transformation in project management, we also see a great change in education and training that will be of interest to those who seek formal renewal.

\subsection{Renewal: Innovations in Training and Education}

One can renew their skill set through education and training. Training involves attaining specific and practical skills, usually through relatively short term learning experiences. Education involves more than theoretical learning in a classroom setting about a wide variety of topics gained over a relatively long term. Training often prepares a learner for the present while education prepares an individual for a future job (Rickman, 2004). While the focus of this paper is about preparing for the future by having a sustainable career, we do want to emphasize the importance of training in project management. Project-oriented participants will do well to review the wide variety of training opportunities offered by professional organizations like the International Project Management Association, Project Management Institute, Association for the Advancement of Cost Engineering International, British Computer Society, and others.

There has been a significant change to the higher education sector that better support successful renewal opportunities: 
1. Multiple Degree Options: There is greater diversity within degrees so that a learner can find a better fit with the degree and their goals (Kofinas et al., 2017). Take the Master of Business Administration (MBA) degree, it was not long ago that an MBA was generic rather than specialized. Now, one can get an MBA in Project Management, MBA in Project and Operations Management, MBA in Business Project Management, etc.

2. Combined Degrees: Universities increasingly offering combined degrees (e.g. a Master of Project Innovation and Master of Project Management ) where the learner graduates with two degrees in a shorter period since electives and core classes are shared between the two degrees.

3. Accelerated Programs: Universities are finding ways to deliver the full degree but within compressed time frames so that the learner achieves the learning outcomes but over a shorter period (Kitchener, 2017). For example, some universities offer classes over three rather than the typical two semesters per year, resulting in students graduating sooner.

4. Intensive Classes: Students can attend intensive classes (e.g., Thursday, Friday and Saturday) so that they can work most of the week and attend classes at the end of the week and on the weekend. Intensive classes improve access to educational renewal (Kofinas et al., 2017).

5. Problem-Oriented: More educational programs are supplementing theoretical learning with problem-oriented thinking supplemented with design thinking (Linton \& Klinton, 2019); that is, they use newly acquired theory to solve problems. By doing so, learning is reinforced.

6. Personalized Learning: Students have more choice within courses to personalize learning and more electives to achieve their learning outcomes often through academic mentorship (Celuch et al., 2017).

7. Interactive: More and more, lectures are replaced with interactive learning (Kofinas et al., 2017) activities like discussions, role plays, peer to peer, board rotation, etc.

8. Flipped Classroom: The flipped classroom is a relatively new teaching approach where the traditional classroom activities are flipped with students complete assigned learning activities before they attend the class. The key advantage is that students in a flipped classroom, have more guidance with higher-order learning activities like analysis and evaluation, to improve learning.

9. Outdoor Learning Spaces: Universities are adding outdoor learning spaces to bring additional diversity to the educational environment (Cassidy et al., 2015). Rather than self-directed group learning and discussions occurring in classrooms, this type of learning environment is especially welcomed by adults who enjoy getting out of the classroom to learn.

10. Workplace Readiness/Authentic Assessment: Perhaps one of the largest changes is that many university programs have adapted their curriculum so that the content is more likely to be used in practice (Kofinas et al., 2017, Celuch et al., 2017). Students increasingly ask that they become workplace-ready as they progress through their program. This feedback has triggered a rethinking of how to assess student learning. This might mean a decline in exams and essays, and an increase in reports, problem-solving exercises, and other types of assignments to approximate what is done in the real world. More institutions are addressing workplace readiness and including authentic assessment (Wiewiora \& Kowalkiewicz, 2019).

11. Digital Badges: Digital badges (micro-credentials) are an emerging online system to recognize accomplishments and competence (DiSalvio, 2016). An awarding organization offers a learning opportunity for a student. Successful students are awarded a digital badge to recognize their competence. The online badge includes key information such as badge name and description, awarding criteria, issuer, learning evidence, date issued, etc. Some universities issue digital badges (e.g. Design Thinker) after one or two subjects are completed to a certain standard (e.g. 65 percent). The student can add this digital badge to their CV and to an online platform like LinkedIn rather than waiting until graduation to show the fruit of their efforts. 
Therefore, while there is great change occurring in the project environment, there are also increased opportunities and modes of learning for those project-oriented participants who are looking for renewal opportunities to boost their sustainable project-oriented career.

\subsection{Conclusion}

Long gone is the norm that one had a job for a lifetime - a stable, singular, and linear career. More project-oriented participants understand the simple concept of supply and demand: if one has competencies that are in demand, then one will likely remain employed. Organizations are becoming more project-oriented and recruit project participants often for particular jobs, and may retain them for additional project work or release them (Huemann, Keegan and Turner, 2007). Many work arrangements are fragile, given changes brought about to how we work (disruptive technologies brought about by the $4^{\text {th }}$ Industrial Revolution) and how we organize for work (more outsourcing and contract work in the Gig Economy). Add work changes to career turbulence external shocks (e.g., family commitments or job promotion), then a project-oriented participant may feel out of equilibrium with an unsustainable project-oriented career. One may have a respected project-oriented job but may need to work long hours to meet deadlines, perhaps resulting in family conflict, stress and possible burnout. Such imbalance is usually not sustainable. One may also have a good project-oriented job but has not expanded or renewed their skill set to be able to contribute to projects involving disruptive technologies. Or they may have a singular career focus, rather than a composite career, with multiple, and perhaps entrepreneurial initiatives.

Career sustainability is complex, non-linear, and fluid; career sustainability is more likely if one addresses at least three key elements: i) holistic integration with one's life, ii) career flexibility and, iii) career renewal (De Vos, Van der Hejden and Akkermans, 2018). Compounding career planning and development is that one's personal goals change over time (De Vos, Van der Hejden and Akkermans, 2018); the sports car that was important in one's twenties becomes less important with marriage and the arrival of twin babies! During one's career, there may be changes in the degree of career fit and sustainability (Parasuraman, Greenhaus and Linnehan, 2000). Hirschi et al., (2019) advise to take a whole-life perspective when living a sustainable career; we might be guided by sustainable career drivers and unsustainable career error messages in order to take proactive planning and action. Unsustainable career error messages can inform us if any of these areas are weak. Career sustainability is of even greater importance to some given that we have an aging population that is expected to work longer in their careers (Stuer et al., 2019).

We conclude this paper with an overview of new trends occurring in education that make renewal more attractive and feasible for most. Project-oriented career sustainability is the individual's responsibility according to a protean view; there are positive actions one can take to have a sustainable career in projects.

The general area of career sustainability research is in its infancy (Mcdonald and Hite, 2018); some call for more research about the nature and dimensions of sustainable careers, indicators of a sustainable career, and general sustainable career theory building (De Vos, Van der Hejden and Akkermans, 2018). However, it appears to this research team that the research opportunities in project-oriented careers are broad and deep. 


\subsection{References}

Adams, R.M. (2006) Sustainable career management in the pharmaceutical industry - lessons and insights, JMMDDPM 6(1):74-76

Ahsan, K., Ho, M. \& Khan, S. (2013) Recruiting project managers: a comparative analysis of competencies and recruitment signals from job advertisements, PMJ 44(5):36-54

Akkermans, J., Seibert, S.E. \& Mol, S.T. (2018) Tales of the unexpected: integrating career shocks in the contemporary careers literature, SAJIP 44(6):1-10

Asuquo, P.N. \& Inaja, A.E. (2013) Fostering sustainable career development and employability among young people in the changing world of work: employers' perspective, Procedia: SBS 84:14921499

Avis, J. (2018) Socio-technical imaginary of the Fourth Industrial Revolution and its implications for vocational education and training: a literature review, JVE\&T 70(3):337-363

Barthauer, L., Kaucher, P., Spurk, D. \& Kauffeld, S. (2020) Burnout and career (un)sustainability: looking into the blackbox of burnout triggered career turnover intentions, J Voc Behav (in press)

Beeching, A.M. (2016) Who is audience?, Arts Humanit High Educ 15(3-4):395-400

Bennett, D. (2009) Academy and the real world: developing realistic notions of career in the performing arts, Arts Humanit High Educ 8(3):309-327

Bozionelos, N., Lin, C. \& Lee, K.Y. (2020) Enhancing the sustainability of employees' careers through training: The roles of career actors' openness and of supervisor support J Voc Behv, (in press)

Bredin, K. \& Söderlund, J. (2013) Project managers and career models: An exploratory comparative study, IJPM 31(6)889-902

Calderón, A. \& Ruiz, M. (2015) A systematic literature review on serious games evaluation: An application to software project management, Comput Educ 87: 396-422

Carayannis, E.G., Kwak, Y.H. \& Anbari, F.T. (2005) The story of managing projects: An interdisciplinary approach, ABC-CLIO Santa Barbara, California

Cassidy, A., Wright, A., Strean, W.B. \& Watson, G. (2015) The interplay of space, place and identity: transforming our learning experiences in an outdoor setting, Collected essays on learning and teaching 8:27-34

Celuch, K., Bourdeau, B., Khayum, M. \& Townsend, L. (2017) The role of the university in accelerated learning and innovation as a regional ecosystem integrator, JRIT\&L 10(1):34-47

Chen, T., Fu, M., Liu, R., Xu, X., Zhou, S. \& Liu, B. (2019) How do project management competencies change within the project management career model in large Chinese construction companies?, IJPM 37(3):485-500

Chin, T., Li, G., Jiao, H., Addo, F. \& Jawahar, I.M. (2019) Career sustainability during manufacturing innovation, Career Dev Int 24(6):509-528 
Chudzikowski, K., Gustafsson, S. \& Tams, S. (2019) Constructing alignment for sustainable careers: Insights from the career narratives of management consultants, J Voc Behv 110:1

Crawford, L., French, E. \& Lloyd-Walker, B. (2013) From outpost to outback: project career paths in Australia, IJPM 31(8):1175-1187

Dahl, M. \& Karlsudd, P. (2015) Leisure-time teachers in a changed profession, Probl Educ 21st Century 68:22-35

De Vos, A. \& Van Der Heijden, Beatrice, Ijm (2017) Current thinking on contemporary careers: the key roles of sustainable HRM and sustainability of careers, Curr Opin Environ Sustain 28(4150)

De Vos, A., Van Der Hejden \& Akkermans, J. (2018) Sustainable careers: towards a conceptual model, J Voc Behv (in press)

DiSalvio, P. (2016) New pathways to credentialing: the digital badge, https://nebhe.org/journal/newpathways-to-credentialing-the-digital-badge/ Accessed 30 Jan 2020

Erdogmus, T., Czermak, M., Baumsteiger, D., Kohn, D., Boller-Hoffecker, A., Schmidt, N. \& Linden, R. (2018) How to support clients and vendors in IT outsourcing engagements: the different roles of third-party advisory services, JITTC (8)2:184-191

Favaro, K. (2015) A Brief History of the Ways Companies Compete, HBR Apr 22, 2015:11-21

Fournier, Geneviève, Zimmermann, Hélène, Masdonati, J. \& Gauthier, C. (2018) Job loss in a group of older Canadian workers: challenges in the sustainable labour market reintegration process, Sustainability 10(7):2245

Frie, L.S., Potting, Karin C. J. M., Sjoer, E., Van Der Heijden, Beatrice I. J. M. \& Korzilius, Hubert P. L. M. (2019) How flexperts deal with changing expertise demands: A qualitative study into the processes of expertise renewal, HRDQ 30(1):61-79

Gartner (2019) Predicts 2019: Establish the foundations for next-generation digital government success, Gartner INC

Gemunden, H.G., Lehner, P. \& Kock, A. (2018) The project-oriented organization and its contribution to innovation, IJPM 36:147-160

Goodwin, K. (2019) Developing self-efficacy and career optimism through participation in communities of practice within Australian creative industries, AJCD 28(2):122-131

Gruden, N. \& Stare, A. (2018) The Influence of Behavioral Competencies on Project Performance, PMJ 49(3):98-109

Hall, D.T., Lee, M.D., Kossek, E.E. \& Heras, M.L. (2012) Pursuing career success while sustaining personal and family well-being: a study of reduced-load professionals over time, JSI 68(4):742-766

Hartman, F.T. (2001) Don't park your brain outside: a practical guide to improving shareholder value with SMART management, Project Management Institute, Newtown Square

Havermans, L., Van Der Heijden, Beatrice I. J.,M., Savelsbergh, C. \& Storm, P. (2019) Rolling into the profession: exploring the motivation and experience of becoming a project manager, PMJ 50(3):346-360 
Herman, C. \& Lewis, S. (2012) Entitled to a sustainable career? Motherhood in science, engineering, and technology, JSI 68(4):767-789

Heslin, P.A., Keating, L.A. \& Ashford, S.J. (2019) How being in learning mode may enable a sustainable career across the lifespan, J Voc Behv (in press)

Hirschi, A., Steiner, R., Burmeister, A. \& Johnston, C.S. (2019) A whole-life perspective of sustainable careers: The nature and consequences of nonwork orientations, J Voc Behv (in press)

Hlanganipai, N. \& Musara, M. (2016) Training and development for career management and talent development in wholesale and retail industry in South Africa, J Psychol Afr 26(2):164-166

Huemann, M., Keegan, A. \& Turner, J.R. (2007) Human resource management in the project-oriented company: a review, IPMJ 25(3):315-323

Huemann, M., Ringhofer, C. \& Keegan, A. (2019) Who supports project careers? Leveraging the compensatory roles of line managers, PMJ 50(4):476-486

Ikediashi, D. \& Aigbavboa, C. (2019) Outsourcing as a strategy for facilities management provision in Nigerian universities, Int J Const Mgmt 19(4):281-290

Iles, P. (1997) Sustainable high-potential career development: a resource-based view, Career Dev Int 2(7):347-353

Jacobs, S., De Vos, A., Stuer, D. \& Van der Heijden, Beatrice I. J. M. (2019) 'Knowing me, knowing You' the importance of networking for freelancers' careers: Examining the mediating role of need for relatedness fulfillment and employability-enhancing competencies, Front Psychol 10:1-14

Kelly, C.M., Strauss, K., Arnold, J. \& Stride, C. (2019) The relationship between leisure activities and psychological resources that support a sustainable career: The role of leisure seriousness and work-leisure similarity, J Voc Behv (In Press)

Kitchener, I.L. (2017) Are accelerated degrees the future for higher education?", Compass: J Lrng Teachg 10(3):1-4

Ko, B. \& Mchenry, C.R. (2018) A model for a career in a specialty of general surgery: One surgeon's opinion, Am J Surg 215(1):8-13

Kobie, N. (2018) What is the gig economy and why is it so controversial? https://www.wired.co.uk/article/what-is-the-gig-economy-meaning-definition-why-is-it-called-gig-economy. Accessed 30 Jan 2020

Kofinas, A., Bentley, Y., Minett - Smith, C. \& Cao, G. (2017) Block teaching as the basis for an innovative redesign of the PG suite of programmes in University of Bedfordshire Business School, Paper presented at Third International Conference on Higher Education Advances, Editorial Universitat Politècnica de València, Valencia, Spain, 21-23 June 2017

Kotecha, A. (2019) Crammer's Corner: Life after certificate of completion of training, SAGE Publications, London, England

Linton, G. \& Klinton, M. (2019) University entrepreneurship education: a design thinking approach to learning, JIAE 8(1):1-11

Mayrhofer, W. (2016) Going the distance: contextualizing and examining the sustainable career, AOM Proceedings 2016(1):14372 
Mcdonald, K.S. \& Hite, L.M. (2018) Conceptualizing and creating sustainable careers", HRDR 17(4):349-372

McKevitt, D., Carbery, R. \& Lyons, A. (2017) A profession but not a career? Work identity and career satisfaction in project management", IJPM 35(8):1673-1682

Merritt, C., Jack, H., Mangezi, W., Chibanda, D. \& Abas, M. (2019) Positioning for success: building capacity in academic competencies for early-career researchers in sub-Saharan Africa", GMH 6

Montgomery, B.L., Dodson, J.E. \& Johnson, S.M. (2014) Guiding the way: Mentoring graduate students and junior faculty for sustainable academic careers, SAGE Open 4(4):1-11

Murray, A. (2009) Can better political governance give Australia an improved political class?, Agenda: JPAR 16(3):63-67

Mutter, J. \& Thorn, K. (2019) Global mobility and the career of the stay-at-home partner, JGM 7(1):88-102

Olsson, C., Kalén, S., Mellstrand Navarro, C. \& Ponzer, S. (2019) Swedish doctors' experiences and personality regarding medical specialty choice: a qualitative study, Int J Med Ed 10:36

Osif, B.A. (2009) Work/life balance, LL\&M 23(1):42-46

Overbaugh, J. (2011) 24/7 isn't the only way: A healthy work-life balance can enhance research, Nature 477(7362):27

Pajic, S., Keszler, Á, Kismihók, G., Mol, S.T. \& Den Hartog, D. (2018) Antecedents and outcomes of Hungarian nurses' career adaptability, Int J Manpow 39(8):1096-1114

Parasuraman, S., Greenhaus, J. \& Linnehan, F. (2000) Time, person-career fit, and the boundaryless career, TOB 7:63-78

Peters, P., Van Der Heijden, B., Spurk, D., De Vos, A. \& Klaassen, R. (2019) Please don't look at me that way. An empirical study into the effects of age-based (meta-)stereotyping on employability enhancement among older supermarket workers, Front Psychol 10(249)

PMI (2019) The future of work: Leading the way with PMTQ, Project Management Institute, Newtown Square

PMI (2018a) Maximizing the benefits of disruptive technologies on projects, Project Management Institute, Newtown Square

PMI (2018b) The project manager of the future: Developing digital-age project management skills to thrive in disruptive times, Project Management Institute, Newtown Square

PMI (2017) Job growth and talent gap: 2017-2027, Project Management Institute, Newtown Square

Rickman, Peter (2004) Education vs training, Phil Now, 47, https://philosophynow.org/issues/47/Education versus Training. Accessed 30 Jan 2020

Rosenblum, N., Kluijtmans, M. \& Ten Cate, O. (2016) Professional identity formation and the clinician-scientist: A paradigm for a clinical career combining two distinct disciplines, Acad Med 91(12):1612-1617 
Schwab, K. (2016) The Fourth Industrial Revolution: what it means, how to respond, World Economic Forum, https://www.weforum.org/agenda/2016/01/the-fourth-industrial-revolution-what-itmeans-and-how-to-respond/. Accessed 30 Jan 2020

Siegel, J. (2013) Getting organized in your job, J Orthop Trauma 27(1):8

Singhvi, A. \& Sachdev, P. (2010) Building a sustainable career in science, Nat Biotechnol 28(4):378

Skulmoski, G. (2001) Project maturity and competence interface, Cost Eng, 43(6):11-18

Spooner, S., Laverty, L. \& Checkland, K. (2019) The influence of training experiences on career intentions of the future GP workforce: a qualitative study of new GPs in England, BJGP 69(685):578

Stronach, M. \& Adair, D. (2010) Lords of the square ring: Future capital and career transition issues for elite indigenous Australian boxers, CCSJ 2(2):46-70

Stuer, D., De Vos, A., Van Der Heijden, B. \& Akkermans, J. (2019) A career perspective of work ability: The importance of resources across the lifespan, IJERPH 16(14)

Suhairom, N., Musta'amal, A.H., Mohammed Amin, N.F., Kamin, Y. \& Abdul Wahid, N.H. (2019) Quality culinary workforce competencies for sustainable career development among culinary professionals, Int J Hosp Manag 81:205-220

Taponen, S., Lehtimäki, L., Karvala, K., Luukkonen, R. \& Uitti, J. (2018) Employment status and changes in working career in relation to asthma: a cross-sectional survey, JOMT 3(1):8

Valcour, M. (2013) Craft a sustainable career, HBR, 15 Jul 2013

Van Der Heijden, B., De Vos, A., Akkermans, J., Spurk, D., Semeijn, J., Van Der Velde, M. \& Fugate, M. (2019) Sustainable careers across the lifespan: Moving the field forward, J Voc Behv, (In press)

Van Driel, M., Deckx, L., Cooke, G., Pirotta, M., Gill, G.F. \& Winzenberg, T. (2017) Growing and retaining general practice research leaders in Australia: How can we do better?, Aus Fam Physician 46(10):757

Venkatraman, S., de Souza-Daw, T. \& Kaspi, S. (2018) Improving employment outcomes of career and technical education students, HESWBL 8(4):469-483

Watson, A. \& Forrest, D. (2012) The bands culture in Victoria, Australia: live music benefits career paths, employment and community, AJME 2:71-81

Wen, Q. \& Qiang, M. (2019) Project managers' competences in managing project closing, PMJ 50(3):361-375

Wiewiora, A. \& Kowalkiewicz, A. (2019) The role of authentic assessment in developing authentic leadership identity and competencies, Assess Eval High Ed, 44(3):415-430

Wilkinson, M., Harper, B., Peacock, J., Morrison, R. \& Getz, K. (2019) Assessing outsourcing oversight practices and performance, TIRS 1:1-9

Witzig, T.E. \& Smith, S.M. (2019) Work-life balance solutions for physicians-It's all about you, your work, and others, Mayo Clin Proc 94(4):573-576 
Xiao, H., Shi, Y. \& Varma, A. (2019) The effects of employee stock ownership plans on career development in a new era, Career Dev Int 24(5):453-474

Zhang, Z., Zhang, L. \& Li, A. (2019) Investigating the effects of reward interdependence and nonfinancial incentives on NPD collaboration in diverse project teams", PMJ 50(6):641-656 